\title{
The case for fire safe cigarettes made through industry documents
}

\author{
M Gunja, G Ferris Wayne, A Landman, G Connolly, A McGuire
}

See end of article for

Tobacco Control 2002;11:346-353

authors' affiliations

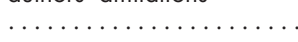

Correspondence to: Geoffrey Ferris Wayne, Massachusetts Tobacco Control Program, 250 Washington Street, 4 th Floor, Boston MA 02108 USA;

geoffmtcp@yahoo.com

Received 10 June 2002 Accepted 1 October 2002

\begin{abstract}
Objectives: To examine the extensive research undertaken by the tobacco industry over the past 25 years toward development of a fire safe cigarette.

Methods: Research was conducted through a web based search of internal tobacco industry documents made publicly available through the 1998 Master Settlement Agreement.

Results: The documents reveal that the tobacco industry produced a fire safe cigarette years ago, but failed to put it on the market. These findings contradict public industry claims that denied the technical feasibility and commercial acceptability of fire safe cigarettes. Internal documents also reveal a decades long, coordinated political strategy used to block proposed legislation and obfuscate the fire safe issue.

Conclusions: Federal legislation mandating fire safe cigarettes is needed.
\end{abstract}

*The TSG comprised one member from: the National Bureau of Standards, American Medical Association, American Furniture Association, National Cancer Institute, National Fire Protection Association, Consumer Product Safety Commission, International Association of Fire Chiefs, American Burn Association/Trauma Foundation, Business and Institutional Furniture Manufacturers Association, Federal Emergency Management Agency, Federal Trade Commission, and four members from the Tobacco Institute. evaluate the technical and economic feasibility of a fire safe cigarette. A 15 member Technical Study Group (TSG) was set up, including representatives of the federal government, public health community, fire safety groups, and the tobacco industry.* In 1987, the TSG reported that it was "technically and economically feasible to produce a cigarette with a significantly reduced propensity for igniting upholstered furniture fires" ${ }^{13}$ The report also concluded that several cigarette design factors were important in reducing ignition propensity, including the use of expanded tobacco, low paper permeability, reduction of citrate as an additive, and decreasing cigarette circumference. ${ }^{14}$

Congress did not mandate that the industry produce and market fire safe cigarettes following the TSG report. Instead, a new bill was passed in 1990 and the 15 member panel, now called the Technical Advisory Group (TAG), reconvened to create a method to test ignition propensity. ${ }^{2}$ After three more years of research, the TAG produced two tests: one used a furniture mock-up on which ignition propensity was measured, and the other used layers of filler paper. Members of the tobacco industry criticised the proposed test, contending that the test methods did not accurately reflect real world conditions. ${ }^{7}$ No further progress was made on legislation on the federal level to regulate the cigarette industry, and subsequent industry discussion about fire safe cigarettes debated the validity of the test results designed by the TAG. ${ }^{15}$

In 2000, progress was made on two fronts: (1) The state of New York passed legislation requiring "fire safe cigarettes" by July 2003; and (2) Philip Morris (PM) introduced fire safe paper technology to their Merit cigarettes. ${ }^{16}$ According to a PM press statement: "The patented cigarette paper ... has rings of ultra-thin paper that are applied on top of traditional cigarette paper during the paper making process. These rings act as "speed bumps" to slow down the rate at which the cigarette burns as the lit end crosses over them.." ${ }^{17}$ The paper bands reduce the mass burn rate and air permeability in the regions surrounding them, which help lower ignition propensity. ${ }^{18}$

Abbreviations: MBR, mass burn rate; PM, Philip Morris; RJR, RJ Reynolds; TAG, Technical Advisory Group; TSG, Technical Study Group 
Table 1 Summary of early patents (before 1980) to produce fire safe cigarette

\begin{tabular}{|c|c|c|c|}
\hline Patent feature & Description & Results & $\begin{array}{l}\text { Number of } \\
\text { patents }\end{array}$ \\
\hline Silicate additives & $\begin{array}{l}\text { Added silicate to paper for } \\
\text { reduced porosity }\end{array}$ & $\begin{array}{l}\text { Decreases burn rate to self extinguish when } \\
\text { unpuffed; increases total delivery }\end{array}$ & 8 \\
\hline Sheath enclosure & $\begin{array}{l}\text { Cigarette enclosed by foil, } \\
\text { silicates, or other fire retardant } \\
\text { substance }\end{array}$ & $\begin{array}{l}\text { Fire safe, although cumbersome and } \\
\text { itconsidered "impractical for routine use" }\end{array}$ & 4 \\
\hline $\begin{array}{l}\text { Banded paper/ } \\
\text { barriers }\end{array}$ & $\begin{array}{l}\text { Band of non-combustible } \\
\text { material in paper or tobacco }\end{array}$ & $\begin{array}{l}\text { Terminates cigarette burning at } \\
\text { predetermined point (self extinguishing) }\end{array}$ & 15 \\
\hline $\begin{array}{l}\text { Asbestos or glass in } \\
\text { paper }\end{array}$ & $\begin{array}{l}\text { Addition of fire resistant } \\
\text { materials in paper }\end{array}$ & $\begin{array}{l}\text { Materials not suitable for use in commercial } \\
\text { cigarettes }\end{array}$ & 4 \\
\hline Burn rate additives & $\begin{array}{l}\text { Addition of additives to paper } \\
\text { to reduce burn rate }\end{array}$ & $\begin{array}{l}\text { Decreases burn rate to self extinguish when } \\
\text { unpuffed; increases total delivery }\end{array}$ & 2 \\
\hline
\end{tabular}

However, PM is the only manufacturer to introduce fire safe technology, and this was made available in its Merit brand (with other brands reportedly on the way), leaving the vast majority of cigarettes in the market unchanged.

Internal industry documents recently released in accordance with the Master Settlement Agreement provide a new opportunity to examine the processes that the tobacco industry used to address the issue of fire safety of their product. The tobacco industry pursued fire safe research for decades, and dozens of prototypes of low ignition propensity and self extinguishing cigarettes were developed. During this time, the industry made public statements that obscured the progress of internal research, and acted politically to disable federal and state interventions. Internal documents reveal that the tobacco industry produced a fire safe cigarette years ago, but failed to put it in the market.

\section{METHODS}

This study examines tobacco industry research and political strategies initiated in the development and introduction of fire safe and low ignition propensity cigarettes. Research was conducted through a web based search of internal tobacco industry documents made publicly available through the 1998 Master Settlement Agreement, using the interface Tobacco Documents Online: (www.tobaccodocuments.org). A preliminary document index search, including optical character recognition whenever available, identified documents using relevant keywords (for example, fire safe, ignition, ignition propensity, burn, etc). Documents were further identified through related projects (Project Hamlet, Reduced Ignition Propensity (RIP), Low Ignition Propensity (LIP)) along with related researchers, management, committees, and meetings. Untitled documents were located through searches of surrounding Bates numbers, and a final search was made based on identification of gaps in document chronology. All identified documents were reviewed by at least two researchers, abstracted, and indexed. Internal industry research ranged within the period from 1971 to 1998, while related patent documents were uncovered beginning in the 1930s. The final set of relevant documents catalogued for this study was approximately 200. The majority of these documents can be accessed online at: http://tobaccodocuments.org/product_ design/documents.php? collection_code $=$ product design\&field_id $=7 \&$ field_value $=\overline{\text { Fire }}+$ Safe + Cigarettes

\section{RESULTS}

Internal research: developing a fire safe cigarette

Internal industry documents reveal that a fire safe cigarette has long been possible. PM asked for a full review of the existing patents on self extinguishing cigarettes in 1979 and found that at least 33 patents existed for means claimed to be useful in making self extinguishing cigarettes ${ }^{19}$ (table 1). Many of these patents have existed for a long time: the first American patent for a self extinguishing cigarette was issued in 1854, and patents were also issued in 1935 and 1936. In 1932, the National Bureau of Standards claimed to have "develop[ed] a treatment which caused the cigarette to go out as soon as thrown away". ${ }^{20}$ In 1974, PM reviewed a self extinguishing cigarette patented by Charles Cohn in 1962, that successfully self extinguished through a silicate solution added to the paper. ${ }^{11}$ A Mother Jones article from 1979 focused on the Cohn patented cigarette and confirmed the product's fire safety. ${ }^{21}$ The tobacco industry was aware of research done before initiation of their own fire safe projects, and knew that they were not breaking entirely new ground on this issue.

Industry programmes to initiate internal research in the field of fire safe and lower ignition propensity cigarettes began alongside the threat of proposed legislation in the late 1970s. PM began fire safe research in 1974. ${ }^{11}$ RJ Reynolds (RJR) and Brown \& Williamson (B\&W) both had extensive testing programmes that began in the late 1970s or early 1980s. ${ }^{22}{ }^{33}$ Lorillard began testing its cigarettes for ignition propensity at least as early as $1980 .{ }^{24}$ Table 2 provides a summary of industry fire safe projects.

Internally, the industry was enthusiastic about the prospect of developing a fire safe cigarette. A PM document in 1977 states: "The question then is how might a self-extinguishing cigarette, that could be sold commercially, be developed. This does not appear to be an impossible task. . . After some thought, I believe that a reasonable commercially acceptable candidate could be developed in approximately one year given a moderate priority."25 Early PM research suggested that adding salt casing or other burn retardants to the paper might be especially promising. It also focused on the use of non-porous or low porosity paper. ${ }^{25}$

In 1979, an RJR memo stated: "the most promising plan to start is with the modification of the cigarette paper. If the paper does not burn back from the fire cone, it will cut off the supply of oxygen and extinguish the coal."26 RJR identified five possibilities for changing the burn rate of cigarette paper, which would in turn affect ignition propensity: (1) changes in additives, (2) changes in paper porosity, (3) paper filler level, (4) non-combustible materials, and (5) melt producing materials in the paper. ${ }^{26}$ These five factors identified in 1979 are nearly identical to those identified by the TSG a decade later in their 1987 report.

In 1983, RJR began testing in earnest the effects that tobacco bulk density, the diameter of the tobacco rod, and the heat energy content of tobacco would have on ignition propensity. ${ }^{27}$ RJR also explored the cost implications of changing their cigarettes to lower ignition propensity, by examining 
Table 2 Summary of internal fire safe research projects

\begin{tabular}{|c|c|c|c|c|}
\hline Project name & Company & Date & Research targets & Results \\
\hline Hamlet & PM & $1982-87$ & $\begin{array}{l}\text { Non-porous paper, banded paper, reduced chalk, } \\
\text { base treated paper, double wrapped paper, blend and } \\
\text { flavour modifications }\end{array}$ & $\begin{array}{l}\text { Achieved low ignition propensity } \\
\text { dcigarette with subjectives at parity to } \\
\text { control }\end{array}$ \\
\hline (Unnamed) & BW & 1983-89 & Non-porous paper, banded paper, slow burn paper & $\begin{array}{l}\text { Abandoned goal of self extinguishment } \\
\text { to target ignition propensity }\end{array}$ \\
\hline LIP (low ignition propensity) & RJR & 1988-90 & Circumference, expanded tobacco, and paper porosity & No consumer acceptable prototype \\
\hline Tomorrow & PM & 1987. & $\begin{array}{l}\text { Mass burn rates targeted via expanded tobacco, } \\
\text { tobacco cut, paper porosity, additives, and banded } \\
\text { wrappers }\end{array}$ & $\begin{array}{l}\text { Achieve successful prototype using } \\
\text { banded wrappers ( } 2000 \text { Merit) }\end{array}$ \\
\hline IP (ignition propensity) & RIR & $1991-$ & $\begin{array}{l}\text { Altered blends and paper porosity, use of burn } \\
\text { additives }\end{array}$ & "No significant difference in acceptance" \\
\hline Reduce ignition propensity & BW & 1993 & $\begin{array}{l}\text { Low porosity paper, burn additives, banded paper, } \\
\text { cross hatch papers }\end{array}$ & No successful prototypes \\
\hline
\end{tabular}

the cost effects of manufacturing cigarettes with reduced circumference, changing the composition of their blends, and reducing cigarette paper porosity. ${ }^{28}$ The company developed prototypes throughout the 1980s that successfully reduced ignition propensity, using new cigarette papers produced by Ecusta Paper Company. ${ }^{29}$ However, following the release of the 1987 TSG report, RJR refocused their fire safe research to targeting consumer acceptability and developing a new test methodology. A statement of their new focus from 1989 lists the following priorities: “1) Develop consumer acceptable prototypes that meet ignition propensity standards ... 2) Evaluate test methodology (ies) that allow accurate, reproducible measurements of IP (Ignition Propensity) standards ... and 3) Provide support to Legal, Steering Committees, and CORESTA committee as required.",30

Other companies made similar progress in their fire safe cigarette projects. B\&W, PM, and RJR all received low ignition paper from the Ecusta and Schweitzer paper companies starting in the early 1980s. In 1983, B\&W developed two cigarette prototypes using Schweitzer papers: "One is a paper which causes a cigarette to self-extinguish in 1.6 to $5.6 \mathrm{~min}$ utes. The other paper lowers the ignition proclivity of a cigarette should it be dropped on a flammable substrate." ${ }^{31}$ Also in the 1980s, B\&W did testing on a Kimberly-Clark banded cigarette paper:

\section{Experiments confirmed that once the burning zone reached a band the cigarette self-extinguished within two minutes. However, because the bands were $17 \mathrm{~mm}$ apart it could take a maximum of six minutes for the smouldering cigarette to self-extinguish. ${ }^{32}$}

In 1980, PM embarked on a fire safe programme called Project Hamlet (in reference to an internal company joke, "To burn or not to burn") whose purpose was to create a fire safe cigarette. ${ }^{33}$ The researchers on Project Hamlet focused on potential additives, tobacco blends, and types of cigarette paper that increased self extinguishing rates. PM also devoted time to experiments with flavour, in an attempt to make the cigarettes acceptable to consumers, which ultimately resulted in a consumer acceptable fire safe cigarette. ${ }^{34}{ }^{35}$ This research was made public by the television programme "60 Minutes" in a story on Project Hamlet that aired on 27 March 1994. ${ }^{36}$

After years of research, PM concluded in 1987 that it did understand how to make a fire safe cigarette.

Historical treatments of ignition-propensity results show that time to ignition measurements are related to the maximum temperatures which smouldering cigarettes will achieve on a standard fabric. Further analysis indicates that these maximum temperatures scale with the mass burn rates of the isolated cigarettes. This reduces the design problem to one of achieving target MBR's [mass burn rates]. ${ }^{37}$

PM realised that achieving these target mass burn rates, and thus producing a low ignition propensity product, was feasible.

In light of the fact that it is now public knowledge that ignition propensity is related to $M B R$, we might want to bring all of our products to MBR targets in stages. We can go quite a way in reducing $M B R^{\prime} s$ by making relatively innocuous changes such as tobacco cut-width, paper permeability, and the type and amount of additives. ${ }^{37}$

Project Tomorrow, another PM program, examined the issue of fire safe cigarettes shortly after the end of Project Hamlet and the release of the TSG report. ${ }^{38}$ Eventually, Project Tomorrow focused on a cigarette that had special bands that would extinguish the cigarette coal if the cigarette was not puffed, and Project Tomorrow succeeded in the early 1990s in creating such a banded cigarette. ${ }^{39}$ Banded cigarette testing was performed as early as 1985 and this banded cigarette was the same cigarette (with minor modifications) that PM released in 2000 as its fire safe Paper Select wrapper, commercially used in the Merit brand. ${ }^{18}{ }^{40}$

\section{Public statements: arguing against the fire safe cigarette}

Although the tobacco industry has been researching the subject of fire safe cigarettes for decades, they have long claimed publicly that a fire safe cigarette is impossible to create. In 1982, the Tobacco Institute opposed fire safe state legislation on the grounds that the technology did not exist to create such a cigarette. ${ }^{41}$ The same claim was reiterated more recently, by RJR in 1994: "[W]e do not know how to make a cigarette that exhibits reduced ignition propensity and is consumer acceptable. We have done considerable research and development to come up with such a cigarette, but extensive consumer testing showed they are not marketable." ${ }^{\prime 2}$ The arguments used by the industry to deny the feasibility of a fire safe cigarette are examined below. These public statements are contradicted in their internal documents. 
Table 3 Summary of successful consumer tests

\begin{tabular}{|c|c|c|c|}
\hline Company & Date & Product & Results \\
\hline Philip Morris & 1985 & $\begin{array}{l}\text { Commercial/non-coventional } \\
\text { blends }\end{array}$ & $\begin{array}{l}\text { "Two models were found to be acceptable to some smoker groups on the complex } \\
\text { wide panel" }\end{array}$ \\
\hline Philip Morris & 1987 & $\begin{array}{l}\text { Non-porous paper, modified } \\
\text { blend }\end{array}$ & "The cigarette models appear to be equally acceptable to the smokers in this test." \\
\hline Brown \& Williamson & 1993 & $\begin{array}{l}\text { Kool Blend with low porosity } \\
\text { paper }\end{array}$ & One prototype was similar to the control in 11 of 13 subjective attributes \\
\hline RJ Reynolds & 1993 & Camel Lights blends & $\begin{array}{l}\text { "The results also indicate that CAMEL LTS } 85 \text { smokers have an overall acceptance } \\
\text { of blend variation prototypes similar to the control." }\end{array}$ \\
\hline
\end{tabular}

The tobacco industry documents are also instructive in understanding why the industry has not produced a fire safe cigarette. One possible consideration was economic-for example, a 1988 RJR analysis suggests that new facilities would be necessary to produce fire safe changes across brands, with costs totalling approximately \$200-300 million. ${ }^{43}$ Another consideration was liability. A British American Tobacco document from 1983 states:

\section{"In view, however of their recent decision taken by the Tobacco Institute not to work actively in the development of self extinguishing cigarettes (for product liability reasons) it will be necessary for $\mathrm{B} \& \mathrm{~W}$ management to define its wishes before GR\&DC is asked to undertake any work." ${ }^{44}$ [emphasis added]}

This document suggests that the industry worked against the drive to create a fire safe cigarette for fear of being held liable for fire deaths and burn injuries. Whether or not these internal industry concerns were responsible for preventing fire safety advancement in subsequent years, the public industry position remained unchanged throughout the 1980s and 1990s.

\section{Consumer acceptability}

The industry has claimed that the design changes necessary for fire safe cigarettes would give the cigarettes a terrible taste or make them unsmokable due to the use of expanded tobacco. Again, the internal industry documents indicate a different story (table 3). In early Project Hamlet testing, changing blends was recognised as the key to flavour, and Graham's Salt was proposed as a possible solution to the flavour problem. ${ }^{35}{ }^{45}$ In 1985, two PM low ignition propensity cigarettes were found acceptable to some smoker groups, and in 1987, PM's latest Hamlet cigarette: "showed no significant differences in the rated means of the control and experimental cigarettes on the attributes of impact throat grab, off-taste aftertaste, and acceptability ... The cigarette models appear to be equally acceptable to the smokers in this test." ${ }^{\prime 46}$

In 1993, RJR produced low ignition propensity prototypes that were similar to their Camel brands and found: "The results also indicate that CAMEL LTS 85 smokers have an overall acceptance of blend variation prototypes similar to the control. The results indicate that the CAMEL LTS 85 smokers found no significant difference among the prototypes with different levels of ESP or among the prototypes with different levels of inherent porosity." ${ }^{48}$ Also in 1993, B\&W created a Kool-like low ignition propensity prototype and tested it against a Kool control. One prototype in particular was essentially similar to the Kool control and in many criteria outperformed the control. ${ }^{49}$
Toxicity

Another argument against low ignition propensity cigarettes stated that design changes needed to create fire safe cigarettes would cause the toxicity of these cigarettes to increase, an interesting argument from the tobacco industry at a time when the industry was denying that cigarettes caused disease. In early testing, smoke machine based deliveries did, in fact, tend to increase in fire safe prototypes. ${ }^{31}$ However, tobacco companies identified which product design components positively and negatively affected smoke delivery and toxicity in low ignition propensity cigarettes. In 1986, for instance, PM recognised that using increased expanded tobacco resulted in lower toxicity, including reduced HCN and CO levels, while flue-cured tobacco resulted in increased levels. ${ }^{50} \mathrm{PM}$ also discovered that on some Hamlet models, perforated wrappers would decrease machine based deliveries while having no effect on ignition propensity. ${ }^{51}$ While working on its banded cigarette programme (which would eventually become Paper Select), PM created two prototypes that had no effect on "tar" delivery levels. ${ }^{39}$ The testing done on the Paper Select also establishes: "there was no meaningful change found in the overall smoke chemistry or biological activity of cigarettes made with this special paper when compared to the same cigarettes made with conventional cigarette paper." ${ }^{52}$ RJR also conducted significant toxicity testing. Internal Ames testing in 1994 showed: "results were not higher for the prototype cigarettes than their respective controls either on a revertant-per-mg-tar basis or a revertant-per-cigarette basis.." ${ }^{13}$ While the toxicity levels of low ignition propensity cigarettes is of major concern, the industry devised means to make their fire safe prototypes no more toxic than their regular cigarettes.

\section{Testing protocols}

The industry has claimed that no testing method could accurately predict whether a cigarette would ignite substrates in real world situations, and has objected that the standards created by the TSG and the TAG would give faulty and contradictory results. ${ }^{54}$ They asserted that the fabrics used in the mock up test either had close to $100 \%$ ignitions or no ignitions at all, which made it very difficult for the industry to understand which cigarettes had more or less ignition propensity. ${ }^{55}$ By challenging the predictability of the cigarette testing, the industry claimed it was impossible to determine whether one cigarette had decreased ignition potential over another.

Contrary to their public statements, however, the internal industry documents reveal that the tobacco companies did have confidence in some of their ignition propensity testing. After six years of testing, in 1986, a confidential PM document reads: "Laboratory tests have been found which differentiate among the small differences in ignition propensities of cigarettes." ${ }^{156}$ In the 1990s, PM developed a computer model of smouldering cigarettes interacting with substrates to better predict a cigarette's ignition propensity. ${ }^{57}$ By 1994, PM had 
Table 4 Impact of industry's fire safe political strategies

\begin{tabular}{llll}
\hline Federal action & $\begin{array}{l}\text { Bill introduced to regulate cigarettes } \\
\text { as fire hazard (1979) }\end{array}$ & $\begin{array}{l}\text { Finds technically and economically feasible to } \\
\text { produce fire safe cigarette (1987) }\end{array}$ & $\begin{array}{l}\text { Methodology for determining ignition } \\
\text { propensity published (1990) }\end{array}$ \\
Industry response & $\begin{array}{l}\text { "Smokers Need Watchers" (personal "Real world methodology" questioned (1987) } \\
\text { responsibility) campaign (1979) }\end{array}$ & $\begin{array}{l}\text { Testing methodology developed by TSG/TAG } \\
\text { will give contradictory results (1990) }\end{array}$ \\
& $\begin{array}{l}\text { Make fire fighters into "third-party } \\
\text { defenders for ourselves" (1980s) }\end{array}$ & $\begin{array}{l}\text { Fire safe cigarettes not consumer acceptable } \\
\text { (1987) }\end{array}$ & $\begin{array}{l}\text { Consumers will behave more carelessly with } \\
\text { fire safe cigarettes (1991) }\end{array}$ \\
& $\begin{array}{l}\text { Call for reduced flammability of } \\
\text { furniture and upholstery (1981) }\end{array}$ & & $\begin{array}{l}\text { Increased education and smoke detectors are } \\
\text { necessary to decrease fires (1998) }\end{array}$ \\
Result & $\begin{array}{l}\text { Bill introduced to determine testing } \\
\text { methodology for ignition propensity } \\
\text { (1987) }\end{array}$ & $\begin{array}{l}\text { Bill introduced to determine testing methodology Federal inaction (ongoing) } \\
\text { forion propensity (1987) }\end{array}$ &
\end{tabular}

Source: Industry documents. ${ }^{2} 13546974757677$

made tremendous progress in developing a test and was enthusiastic about the validity of these tests:

\begin{abstract}
We believe a reasonable protocol is evolving. Consistent relationships/trends have been determined for IP test outcome with cigarette parameters and very importantly with fabric properties. This knowledge is a step forward in understanding mechanisms of cigarette-induced ignitions and modeling/predicting test results. It is also important in assessing the validity and relationships of IP tests on any given substrate(s). ${ }^{58}$
\end{abstract}

This internal method matches the substrate ignition criteria proposed by the TAG committee, and successfully relates testing results to both cigarette parameters and fabric properties. This demonstrates that a testing methodology was developed within the industry that strongly predicts real world situations.

\section{Shifting responsibility from the product to the smoker} RJR advanced the theory that if produced, fire safe cigarettes may actually cause more fires because people may handle the cigarettes more carelessly if they think that their cigarettes are completely fire safe. In a memo providing talking points for a meeting with Congressman Moakley, RJR claimed:

\section{Qualitative consumer research at RJRT has suggested that consumers cannot distinguish between the concepts of 'reduced ignition-prone' and 'fire-safe'. Open-end responses to the former concept indicate that consumers would likely behave more carelessly in all smoking settings. ${ }^{59}$}

However, testing performed at RJR less than a year later directly contradicts the claim made to Congressman Moakley.

\section{When asked if they would behave differently - that is less careful [sic] when smoking this new product - virtually all respondents said they would not alter their current smok- ing behavior. Most people said they would be just as careful with any cigarette, because it still could start a fire, or put a burn in upholstered furniture or clothes, etc. $^{.00}$}

RJR's own testing undermines the claim that fire safe cigarettes would cause more fires. RJR also attempted to deflect responsibility for cigarette caused fires from the industry by placing the blame on smokers; one RJR document states: "There must be some personal responsibility - even a child knows not to take a fire to bed.",61
Political strategies: influencing fire safe legislation

Although internal research has produced viable fire safe prototypes, the industry maintained a concerted effort to fight legislation mandating fire safety standards for cigarettes. Industry documents reveal initial efforts as early as 1981-82, when the industry encouraged furniture and upholstery manufacturers to reduce the flammability of their products to take focus off rising calls for a fire safe cigarette. ${ }^{62}$ As proposed initiatives legislating a fire safe cigarette continued, the industry developed a comprehensive strategy that was successful in preventing the enactment of meaningful fire safe legislation. This point was highlighted in a 1992 speech to the annual board of directors meeting of the Lorillard Tobacco Company, when Andrew Tisch, chairman and CEO of Lorillard, boasted of how effectively the industry staved off regulatory legislation, noting: "Legislation mandating "firesafe" cigarettes was introduced in five states and defeated in all ..." ${ }^{\prime 3}$ As recently as 1997 the Tobacco Institute maintained a map entitled "Fire safe cigarette threats" indicating in which states fire-safe cigarette legislation was likely to be proposed. ${ }^{64}$

Recognising that fire safe cigarettes were a potentially problematic public issue, the industry sought to change public perception of the fire safe question. In a 1993 internal corporate presentation for PM, Tina Walls, PM's director of government affairs for the western half of the nation, explained how PM had used the "broadening" strategy to defeat several types of legislation including fire-safe cigarettes: "[W]e try to change the focus on the issues . . . Cigarette-related fires become an issue of prudent fire safety programs.." ${ }^{15}$ In addition to changing the scope of the debate, the Tobacco Institute also realised the power of "fire-scarred victims interviewed by the news media and paraded before legislative committees" ${ }^{3}$ In turn, it embarked on making the industry appear concerned for victims of fires caused by cigarettes. Changing public perception of the industry and the issue was a vital component of the industry's attempt to defeat legislation (table 4)

In addition to changing public perception, the industry also successfully co-opted potential proponents of fire safe cigarettes. One document sums up the industry's strategy:

You have to try to understand whom you have to neutralize in advance, who is a potential threat to you and then how do you make common cause with that category of individuals or companies or group or whathaveyou [sic] so that you can neutralize them. ${ }^{66}$

To give legislators the impression that the industry was concerned about fire safety and to quell calls for fire safe cigarettes from national fire service organisations, the Tobacco Institute embarked on a massive programme of funding fire safety organisations to provide public education about fire 
Table 5 Tobacco Institute spending on support of fire organisations

\begin{tabular}{|c|c|c|c|}
\hline & $\begin{array}{l}1990 \text { Budget } \\
\left(\$ \mathbf{S}^{\prime} 000\right)\end{array}$ & $\begin{array}{l}1990 \text { Estimated } \\
\left(\$^{\prime} 000\right)\end{array}$ & $\begin{array}{l}1991 \text { Budget } \\
\left(\$^{\prime} 000\right)\end{array}$ \\
\hline Grants to local fire safety organisations & 120 & 80 & 100 \\
\hline National Volunteer Fire Council & 40 & 40 & 35 \\
\hline Zoeller \& Associates (fire prevention consultants) & 40 & 40 & 20 \\
\hline Pan Education Institute fire prevention education & 25 & 25 & 15 \\
\hline National Association of State Fire Marshals & - & 10 & 15 \\
\hline Burn Concerns & 20 & - & 10 \\
\hline Congressional Fire Services Institute & 10 & 10 & 10 \\
\hline International Association of Fire Chiefs & 10 & 10 & 10 \\
\hline International Association of Black Professional Fire Fighters & - & 5 & 5 \\
\hline Miscellaneous (production of materials, psa's, etc) & 35 & 30 & 35 \\
\hline Total & 320 & 270 & 270 \\
\hline
\end{tabular}

safety. For instance in 1990, the Tobacco Institute spent $\$ 320000$ on grants to local fire safety organisations and other fire safety associations, while also spending $\$ 480000$ on consulting and PR firms for fire safety issues. ${ }^{67}$ Seizing on the fact that fire departments nationwide were underfunded at that time, the tobacco industry saw a benefit in promoting a sense of job security among fire service employees ${ }^{3}$ (table 5 ).

The Tobacco Institute also started a vast national programme of financial aid and in-kind contributions to both local and state fire departments across the country, in an attempt to neutralise firefighter hostility toward cigarette manufacturers and their products, and quell calls for a fire safe product. In addition to extensively funding these agencies, the Tobacco Institute built alliances with key fire safety officials and organisations nationwide. Members of the Tobacco Institute sought seats on advisory boards of fire safety organisations and arranged to be listed as presenters at fire service conferences wherein they would promote tobacco industry assistance to the fire service ${ }^{68}$ The Tobacco Institute also created promotional materials to tout its involvement with fire safety public education, such as calendars, brochures, advertisements, bumper stickers, and a fire safety video that institute members planned to present to legislative committees to show they were concerned about the fire safety issue. ${ }^{67}$ As one example, in its goals for 1987 the Tobacco Institute lists expectations of five articles placed by fire service personnel in fire journals and 200 working relationships with fire officials and other public officials on fire prevention programmes. ${ }^{69}$

By 1990, the Tobacco Institute had spread these efforts across the USA. It had developed working relationships with officials in more than 500 key fire departments across the country. Fire safety materials produced by the Tobacco Institute were being used in thousands of fire departments around the country, including those in more than 200 major cities, and its grants had been awarded to more than 85 state, regional, and national fire service organisations. ${ }^{68} 70$

The industry considered their accomplishment of silencing the firefighting community on the issue of the self extinguishing cigarette to be one of their finest success stories. In fact, PM exhibited the strategy as a textbook example of how to effectively neutralise a credible enemy. In a transcript of a presentation given at a PM worldwide corporate affairs meeting in 1984, PM executive Allan Miller explains:

Who would normally be involved in the selfextinguishing cigarette on the other side of the fence? Probably the fire-fighting community. As you know in the United States, we have put a huge amount of time into helping all the organized groups of professional and volunteer fire-fighters. They get such help from us that is monumental. And then when we need them to stand up and say, not cigarettes that cause fire in 99.9 percent of the cases, we get their cooperation. But that's because we have cultivated them and helped them achieve some of their goals and we have seen that they are a potential enemy that has real credibility. That's the greatest credibility, your potential enemy. We had turned them around and made allies, third party defenders for ourselves. All of this involves a process of logic. To find common ground, to find your natural friends; to find your natural enemies and if possible, the ways in which you can neutralize them... ${ }^{60}$

The Tobacco Institute's nearly 15 year long, multi-pronged effort to stop the fire service from opposing the tobacco industry on the issue of self-extinguishing cigarettes and stave off regulation proved a remarkable success. The institute noted by 1991 that it had significantly reduced fire fighter hostility towards the industry and their products. ${ }^{67}$

\section{DISCUSSION}

The tobacco industry has opposed fire safe cigarette legislation for the last 25 years. The industry has claimed, on an assortment of grounds, that it was not feasible to produce a fire safe cigarette. At various times, the industry stated that: (1) fire safe cigarettes would be unacceptable to consumers; (2) that no testing method would accurately predict whether a cigarette was fire safe; (3) that fire safe cigarettes would increase toxicity; and (4) that cigarettes were not the primary problem of cigarette caused fires. Internal industry documents, however, contradict the industry's public claims. The industry has done research on this issue for more than 25 years, and has had numerous projects dedicated to creating a fire safe cigarette. A fire safe cigarette with demonstrated consumer acceptability was developed years ago, and the tobacco industry did not place it on the market.

At the same time, the tobacco industry engaged in a long term strategy to neutralise their opposition on this issue and thus delay legislation of a fire safe cigarette. Strategies included making generous grants over long periods of time to local, state, and national fire service organisations and fire departments throughout the USA to gain the goodwill of fire protection groups, and making them allies rather than opponents on the fire safe issue. The tobacco industry also attempted to deflect attention from product design by "broadening" the self extinguishing cigarette issue into one of overall fire safety, and pouring money into fire safety programmes featuring materials that had nothing to do with cigarettes, like calendars and videos. Efforts were even extended to shift the burden of fire prevention from the industry to the vigilance of smokers and non-smokers. Because much of the information distributed on fire deaths originates from fire department and 


\section{What this paper adds}

It is well documented that fires caused by cigarettes are responsible for 1000 deaths and billions of dollars in other damages each year in the USA. For years, the tobacco industry has claimed that they do not know how to manufacture a commercially viable fire safe cigarette. However the recent release of industry documents as a result of the Master Settlement Agreement has shed new light on what the industry knew about fire safe cigarettes.

These internal company documents reveal that the tobacco industry has known how to create a fire safe cigarette for some time. The documents also illuminate tactics used by the tobacco industry to block and otherwise influence fire safe legislation. This article will inform effective use of state and federal legislation to address cigarette related fires. It will also add to understanding of industry counter strategies that are aimed at and directly impact public health outcomes.

fire safety organisations, tobacco industry influence on these organisations is likely to have a broad effect on the dissemination of information within the general media.

Failure to introduce fire safe products to market appears to have been due in part to fear of past product liability, coupled with the potential expense associated with introducing new fire safe technology across brands. Given that the industry has not voluntarily placed fire safe cigarettes on the market, it is important that state and/or federal fire safe legislation be passed. Because PM has marketed its Paper Select paper we know that fire safe paper is technologically and commercially possible. No other company has introduced any sort of fire safe cigarette on the market. Thousands of lives can be saved with the adoption of fire safe cigarettes. The industry has not acted voluntarily on this issue and, lacking federal legislation, burn victims could also initiate product liability suits, thus forcing the industry to institute tough fire safety standards.

\section{ACKNOWLEDGEMENT}

This research was funded through a grant from the National Cancer Institute.

\section{Authors' affiliations}

M Gunja, G Ferris Wayne, G Connolly, Massachusetts Department of

Public Health, Boston, Massachusetts, USA

A Landman, American Lung Association of Colorado, Glade Park,

Colorado, USA

A McGuire, Trauma Foundation, San Francisco, California, USA

\section{REFERENCES}

1 Leistikow BN, Martin DC, Milano CE. Fire injuries, disasters, and costs from cigarettes and cigarette lights: a global overview. Prev Med 2000;31 (2 Pt 1):91-9.

2 McGuire A. How the tobacco industry continues to keep the home fires burning. Tobacco Control 1999;8:67-9.

3 Tobacco Institute. Appendix B: Elements of Positive Strategy New Initiatives for Industry Action, Tobacco Institute, 1981 (Estimated), Bates No. 04330334-0378.

4 Gannon WF. Visit of Dr. Joseph Clark, Philip Morris, 26 October 1976 Bates No. 2024781309-1310.

5 Tobacco Institute. Issue Brief "Self Extinguishing" Cigarette Legislation Tobacco Institute, April 1987. Bates No. TIFL0071560-1561.

6 RJ Reynolds. "Fire-Safe" Cigarettes Legislative Status and Implications, RJ Reynolds Tobacco Company, 1 February 1990, Bates No. 508544401-4408.

7 RJ Reynolds. Status of Research Regarding Low Ignition Propensity Cigarettes, RJR Tobacco Company, 5 May 1993, Bates No. $2021302717-2743$

8 Botkin J. The fire-safe cigarette. JAMA 1988;260:226-9.

9 Philip Morris. Cigarette, patented by M.X.C. Weinberger, 7 April 1933, Bates No. 100279546-9548

10 Philip Morris. Self Extinguishing Cigarette, patented by F.C. Guida, 11 January 1961, Bates No. 1000279518-9520.
11 Philip Morris. The Self-Extinguishing Cigarette, Philip Morris, 31 July 1974, Bates No. 1000279493-9494.

12 Philip Morris. Difficulte Flammable Cigarette Wrapper, patented by S.E. Seaman, 25 May 1933, Bates No. 1000279543-9545.

13 Technical Study Group. Toward a less fire-prone cigarette: final report of the technical study group on cigarette and little cigar fire safety. Bethesda, Maryland: US Consumer Product Safety Commission, October 1987.

14 RJ Reynolds. "Fire-Safe" Cigarettes (Cigarette Ignition Propensity), RJ Reynolds Tobacco Company, 1989, Bates No. $511564140-4160$.

15 Cigarette Ignition Propensity Joint Venture, Technical Overview of Cigarette Industry Research on Ignition Propensity Test Methods, July 1993, Bates No. $511035860-5880$

16 Trauma Foundation. URL: http://www.ff.org/tf/injuries/cigar5.shtml

17 Philip Morris. "Philip Morris U.S.A. to Launch New Cigarette Paper Nationwide on all Merit Cigarettes", Philip Morris press release, 12 July 2000.

18 Garg R, Reynolds B, Phan T. The development of banded cigarette paper to reduce ignition propensity of cigarettes. Philip Morris, 2000 (estimated)

19 Philip Morris. A Review of 33 U.S. Patents Disclosing Means Claimed to be Useful in Making a Self-Extinguishing Cigarette, Philip Morris, November 19, 1979 , Bates No 1002804544-4547.

20 RJ Reynolds. Historical Highlights of the campaign for a Fire Safe Cigarette, RJR Tobacco Company, November 1992, Bates No. 508509884-9888

21 O'Malley, Becky, "Cigarettes \& Sofas; How the Tobacco Lobby Keeps the Home Fires Burning", published in Mother Jones, July 1979, Bates No. $2020186871-6878$

22 Rodgman A. Modification of the Burn Rate of Unpuffed Cigarette, RJR Tobacco Company, 10 September 1979, Bates No. $508511155-1156$

23 Brown \& Williamson. Schweitzer Papers for Cigarettes which Self-Extinguish or have Reduced Ignition Proclivity/324, Brown \& Williamson, 22 August 1983, Bates No. 620348647-8649.

24 McGeady JC. SEM Examination of Self-Extinguishing Type Cigarette, Lorillard, 15 January 1980, Bates No. 87901745-1751.

25 Merritt HB. Self-Extinguishing Cigarette, Philip Morris, 6 January 1977 Bates No. 2020186850-6853.

26 Rodgman A. Modification of the Burn Rate of Unpuffed Cigarette, RJR Tobacco Company, 10 September 1979, Bates No. $508511155-1156$

27 RJ Reynolds. Proposal. Investigation of Some Design Parameters for the Manufacture of Fire Safe Cigarettes, RJR Tobacco Company, 7 April 1983, Bates No. 508486923-6970.

28 RJ Reynolds. Reduced Cigarette Ignition Propensity, RJR Tobacco Company, 9 December 1988, Bates No. 507622260-2262.

29 Di Marco G. Robert, No Title, RJR Tobacco Company, July 30, 1984 Bates No. 504750971-0972.

30 Lewis LS, Gee JW. 1989 Objectives. Low Ignition Propensity Group, 30 November 1988, Bates No. 508612414

31 Brown \& Williamson. Evaluation of Schweitzer's Self-Extinguishing and Low Ignition Proclivity Cigarette Papers, Brown \& Williamson, 19 December 1983, Bates No. 505005146-5149.

32 Markin DA. Evaluation of the Kimberly Clark Self-Extinguishing Cigarette, Brown \& Williamson, 16 January 1989, Bates No. 570235133-5142.

33 RJ Reynolds. R\&D. 'Current R\&D Projects and Directions', Philip Morris, 1983, Bates No. 1003475173-5187

34 Hausermann M. Monthly Development Summary, Philip Morris, 12 October 1983, Bates No. 2001213423-3425.

35 RJ Reynolds. Project Hamlet. Philip Morris, 1985 (Estimated), Bates No. 2020356517-6543.

36 Philip Morris. Statement of Philip Morris USA before the Subcommittee on Commerce, Philip Morris, 20 April 1994, Bates No. 570362055-2058

37 Philip Morris. Project Tomorrow - Status and Plans, Philip Morris, 25 November 1987, Bates No. $1002816087-6088$

38 Moogalian C. Project Tomorrow Prototype, Philip Morris, 25 October 1989, Bates No. 2020113220.

39 Phiilip Morris. 5A01 Project Tomorrow - Banded Paper Program, Philip Morris, 1994, Bates No. 2054768090-8104.

40 Philip Morris. 1985 Accomplishments - 4009, Philip Morris, 9 January 1986, Bates No. 2025340472.

41 Newman FS. Self Extinguishing Cigarettes. Philip Morris, 20 May 1982. Bates No. $2022963801-3802$.

42 RJ Reynolds. Cigarette Ignition Propensity Issues, RJR Tobacco Company, March 1994, Bates No. 508690094-0103.

43 RJ Reynolds. Reduced Cigarette Ignition Propensity, RJR Tobacco Company, 9 December 1988, Bates No. 507622260-2262

44 Blackman LCF. Visit by Dr L.C.F. Blackman to B\&W, Louisville, 3 to 7 October 1983, Technical Notes, British American Tobacco Company, 27 October, 1983, Bates No. 109873975-3984.

45 Greene RK. Project Hamlet, Graham's Salt, Philip Morris, 21 August 1985, Bates No. 2020356664-6671

46 Goodman BL. Project 4009 - 1984 Accomplishments, Philip Morris, 14 January 1985, Bates No. $202210549-0551$.

47 Smith AD. Hamlet Test, Philip Morris, 29 April 1987, Bates No. 2051023053-3054.

48 Charles S. Project IP - Sensory Acceptance, RJR Tobacco Company, 6 August 1983, Bates No. 508539091-9106.

49 Goodman PA. Dupont Sensory Results, Brown \& Williamson Tobacco Corporation, 21 June 1993, Bates No. 587000503-0509.

50 Goodman B. Project Hamlet; Analytical Data for Committee Samples, Philip Morris, 16 May 1986, Bates No. 2020102247-2252. 
51 Greene RK. Project Hamlet; The Effect of Wrapper Perforation, Philip Morris, 1986, Bates No. 2020102443-46.

52 Philip Morris. Philip Morris U.S.A. to Launch New Cigarette Paper Nationwide on All Merit Cigarettes, Philip Morris Press Release, 12 July 2000.

53 Reed EA. Ames Test Data on Ignition Propensity Cigarette, RJR Tobacco Company, 26 April 1993, Bates No. 508073428.

54 Lewis LS. Cigarette Ignition Propensity. A brief history of US activities, RJR Tobacco Company, 30 November 1990, Bates No. 508573360-3362.

55 RJ Reynolds. Status of Research Regarding Low Ignition Propensity Cigarettes. A Discussion of Three Unresolved Issues that make Cigarette Ignition Performance Standards Presently Infeasible, RJR Tobacco Company, 5 May 1993, Bates No. 2021302717-2743.

56 Philip Morris. Reduced Ignition Propensity, Philip Morris, January 1986 Bates No. 2020101909.

57 Dwyer RD, Shafer KH. Project Tomorrow, Second Quarter 1992, Philip Morris, 1992, Bates No. 2022153668-3673.

58 Waymack BE. Individual accomplishments, Jan-June 1994, Philip Morris, June 29, 1994, Bates No. $2051202450-2451$

59 Townsend D. Cigarette Ignition Propensity, RJ Reynolds Tobacco Company, 3 May 1990, Bates No. 508686378-6382.

60 Scism A. Product Research Report, RJ Reynolds Tobacco Company, 1 March 1991, Bates No. 508596936-6947.

61 RJ Reynolds. Ignition Propensity Key Points, RJR Tobacco Company. April 1994. Bates No. TIMN0339146-9151.

62 Toohey WD. Untitled. Tobacco Institute, 19830321, Bates No. TIFL0522380/2381.

63 Tobacco Institute. Comments for Andrew Tisch, Tobacco Institute Annual and Board of Directors Meeting, Tobacco Institute, 10 December 1992, Bates No. TIMN0405163-5182.
64 Tobacco Institute. 1997 Draft Proactive Forecast Smoking Restrictions, Tobacco Institute, 26 September 1996, Bates No. TI15731 102-1 106.

65 Walls T. Grasstops Government Relations, Philip Morris, 30 March 1993, Bates No. $2024023252-3265$.

66 Blake J, Dowling J, Florio D, et al. Workshop - Dealing with the Issues Indirectly: Constituencies, Philip Morris, 1984 (Estimated), Bates No. 202542 1934-2000

67 Tobacco Institute. Proposed Budget 1991, Tobacco Institute, 1991, Bates No. TIMN0390579-0803.

68 Fernicola, KL. Untitled, Tobacco Institute, April 14, 1989, Bates No. TIMN0033019.

69 Stuntz S, Buckley M. Accidental Fire Issue - August 1986 Report, Tobacco Institute, 18 September 1986, Bates No. TIMN 339146-9151.

70 Tobacco Institute. Fire/Public Service Programs, Tobacco Institute, 1986, TIMN0049849-9856.

71 RJ Reynolds. Reduced Cigarette Ignition Propensity, RJR Tobacco Company, 9 December 1988, Bates No. 507622260-2262.

72 Moogalian C. Project Tomorrow Prototype, Philip Morris, 25 October 1989, Bates No. 2020113220.

73 Smith AD. Hamlet Test, Philip Morris, 29 April 1987, Bates No. 2051023053-3054.

74 Toohey WD. Untitled. Tobacco Institute, 19830321, Bates No. TIFLO522380-2381.

75 RJ Reynolds. Cigarette Ignition Propensity Issues, RJR Tobacco Company, March 1994, Bates No. 508690094-0103.

76 Townsend D. Cigarette Ignition Propensity, RJ Reynolds Tobacco Company, 3 May 1990, Bates No. 508686378-6382.

77 RJ Reynolds. Design Standards or Performance Standards - Ignition Propensity, RJR Tobacco Company, 10 February 1998, Bates No. $518397492-7494$. 